\title{
Biological explorations of Sinai: flora and fauna of Wadi Isla and Hebran, St Katherine Protectorate, Egypt
}

\author{
Samy Zalat ${ }^{1 *}$, Francis Gilbert ${ }^{2}$, Hassan Fadel ${ }^{3}$, Magdi Shaban El-Hawagry ${ }^{4}$, \\ Mahmoud Saleh ${ }^{4}$, Soliman Kamel ${ }^{5}$ \& James Gilbert ${ }^{6}$
}

1. Department of Zoology, Faculty of Science, Suez Canal University, Ismailia, Egypt.

2. School of Biology, University of Nottingham, Nottingham, UK.

3. Department of Entomology, Faculty of Science, Ain Shams University, Cairo, Egypt.

4. Department of Entomology, Faculty of Science, Cairo University, Giza, Egypt.

5. Department of Plant Protection, Suez Canal University, Ismailia, Egypt.

6. Department of Biology, University of Maryland, College Park, MD USA

\begin{abstract}
A comprehensive survey was accomplished for two of the most important and beautiful wadis in the Sinai, Wadi Isla \& Hebran. The biodiversity of the two wadis are surveyed including plant species and their associated insects, spiders and scorpions. The list includes 20 plant families with 51 species, 8 insect orders with 54 families and 138 species, and 4 arachnid orders with 17 families and 23 species. The highest number of species recorded were Coleoptera and Hymenoptera.
\end{abstract}

Keywords: Biodiversity, checklist, plants, insects, spiders

\section{Introduction}

The mountainous region of southern Sinai probably contains a greater biodiversity than in the rest of Egypt. A large section of the area was declared a Protectorate in 1996, centered upon the town of St Katherine (altitude $1600 \mathrm{~m}$ ) with its world-famous 6th century monastery built on the traditional site of the 'burning bush' of the Bible, at the foot of Mt Sinai. From the mountain of St Katherine, at $2641 \mathrm{~m}$ the highest point in Egypt and marking the watershed of the peninsula, wadi systems drain eastwards towards the Gulf of Aqaba, and westwards towards the Gulf of Suez. Although southern Sinai is classified as 'very arid' (Zahran \& Willis, 1992), there is in fact a great deal of water draining down the wadis, sometimes as violent and destructive flash floods, but under normal circumstances most of the water is underground, occasionally surfacing to produce short sections of freely flowing permanent water. Sparse vegetation occurs everywhere, but the wet areas are particularly rich with plants and consequently with insects and other animals.

Because of the recent political history of the Sinai, little is known about the fine detail of the distributions of the different taxa. Such detail is vital in the rational planning of the management of the Park, especially in the light of the position of the monastery and the importance of tourism to the economy of Egypt. The rich biodiversity of the Park is exemplified by the butterflies (67\% of the 60 species of Egypt, including two endemics: Larsen 1990, Gilbert \& Zalat 2008) and the plants (estimates vary, but a figure of 450 has been quoted with more than 30 endemics, see Boulos 1998-2004). This report documents an expedition to record and map the biodiversity of insects and their associations with plants within the St Katherine Protectorate. We chose to concentrate upon Wadi Isla, a traditional camel route between the regional capital on the Red Sea coast, El Tur, and the town of St Catherine. Wadi Isla opens onto the Plain of El Qa'a, a wide and gently sloping plain separating the mountains from the Red Sea (Map 1). The wadi is well known amongst the local Bedouin for its rich water resources, but rather few biologists have visited it: we know only of some entomologists (Alfieri, Efflatoun, Zalat); occasional records of collected insects show that some others have also been in the wadi (e.g. Dumont 1991; Theodor 1980, Freidberg \& Kugler 1989). We returned to St Catherine via Wadi Hebran, a wadi which runs parallel to but north of Wadi Isla, 
and which also opens onto the Plain of El Qa'a: Wadi Hebran is equally poorly known entomologically.

\section{Methods}

The expedition lasted nine days between 31st July and 8th August 1994. Each day was spent either walking along the wadi, collecting arthropods from under stones, or by sweeping or beating plants, or by collecting visitors of flowers. At certain places in Wadi Isla we spent whole days observing flowers of Mentha lavandulacea Willd. (Labiatae) as part of a more specialized study of the insect-plant interactions of this plant. All specimens were preserved in ethyl acetate vapor before pinning on return, and voucher specimens of all taxa are lodged at the collection of the Environmental Research Center (ERC) of Suez Canal University situated in the town of St Catherine. At each camp site we took our position using a hand-held GPS receiver (Trimble Ensign, Trimble Navigation UK LTD, UK) accurate to $\pm 200 \mathrm{~m}$, given enough satellites in the right places; 3-dimensional accuracy is measured by the Positional Dilution of Precision (PDOP) which depends on the number of geometry of the satellites. The full names of all the plants and insects we recorded are given in Table 1 and Table 2 respectively. The route of the expedition is shown on Fig 1. Plants names follow Boulos (19982004).

Fig 1: Map of southern Sinai, with the boundary of the St Katherine Protectorate (black) and the route of the expedition (yellow) southwest down Wadi Isla, north-west along the boundary ofthe mountains with the Plain of El Qa'a, and up Wadi Hebran.

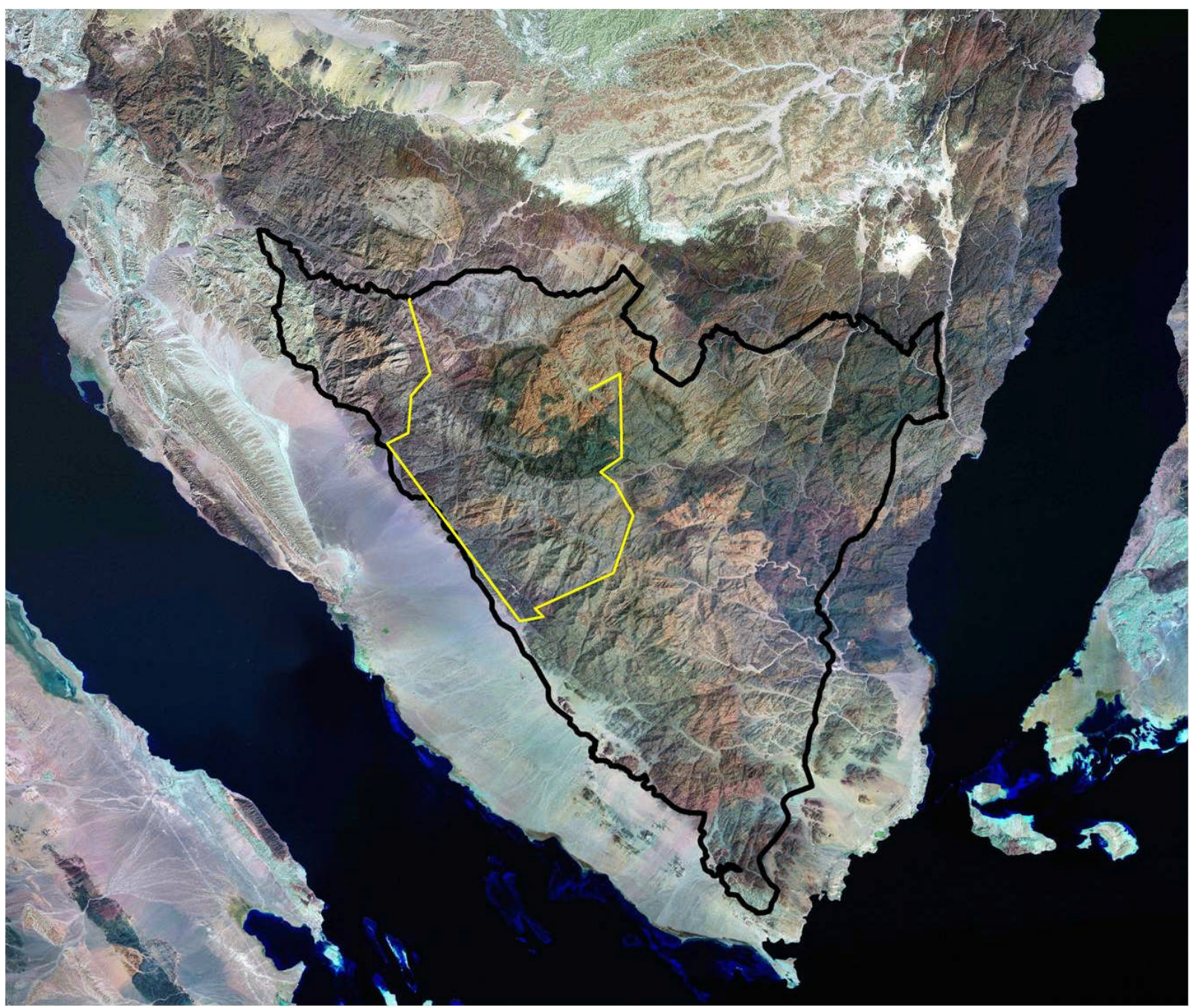




\section{Results}

Day 1: We were taken by Land Rover from Suez Canal University's Environmental Research Center at St Catherine to the plain of El Rahaba, a wide plain surrounded by low hills and mountainous ridges. This plain has no running water at any time except during flash floods, but nevertheless there is a great deal of vegetation, dominated by Seriphidium herba-alba and to a lesser extent Artemisia judaica, Achillea fragrantissimum and Zilla spinosa; Peganum harmala and Fagonia tristis are also frequent.

From here we were joined by three camels and a Bedouin guide from the Awlad Ali, Hussein No'man, skilled at identifying plants. We then crossed over into the Wadi Isla drainage system, which at this point is called Wadi Tarafa. Again the dominant plants are Seriphidium herba-alba, Peganum harmala, Zilla spinosa and Fagonia tristis. Also encountered were Raetam raetam, Alkanna orientalis, Stachys aegyptiaca, Hyoscyamus boveanus, Tamarix aphylla, Gomphocarpus sinaicus, Teucrium polium, Micromeria sinaica, Zygophyllum album, Reaumuria hirtella, Acacia tortilis raddiana, date palms Phoenix dactylifera, and wild figs Ficus pseudosycomorus. In addition we recorded Euphorbia obovata, a rare Sinai endemic classified as endangered (Gamal El Din 1992) which, according to our guide, only occurs in the Rahaba area. We camped at $28^{\circ} 23^{\prime} 37.2^{\prime \prime} \mathrm{N}, 34^{\circ} 00^{\prime} 40.5^{\prime \prime} \mathrm{E}$ at an altitude of $1530 \mathrm{~m}$ (PDOP $=2.8, \mathrm{n}=6$ satellites).

Day 2. The next day was spent walking down Wadi Tarafa, through Wadi Zeliga, to Wadi Orma, all part of the Wadi Isla drainage system; we camped at the junction between Wadi Zeliga and Wadi Orma at $28^{\circ} 18^{\prime} 35.0^{\prime \prime} \mathrm{N}, 33^{\circ} 59^{\prime} 3.2^{\prime \prime} \mathrm{E}$, at an altitude of $870 \mathrm{~m}$ (PDOP $=3.2$, $\mathrm{n}=5$ satellites). Wadi Tarafa is dominated by Zilla spinosa, Pulicaria undulata, Artemisia judaica and Seriphidium herba-alba, and others as before, but there are small patches of Mentha lavandulacea; Hyoscyamus boveanus begins to be abundant, and there are increasing numbers of the two species of Capparis, $C$. sinaica being more common than $C$. spinosa.

Some of the large red edible fruits of $C$. sinaica were infested with insect larvae, probably Diptera. As is common with many Sinai plants, only a few flowers of $C$. sinaica bloom each day and all stages from flower to dehisced fruit are present on the same plant; flowers last only a single day, and wither rapidly during the day of Opening.

Other plants recorded this day were Ephedra, two species of Cleome (africana and droserifolia), Reseda urnigera, Caylusea hexagyna, Pulicaria incisa, Trichodesma africanum, Launaea spinosa, Ochradenus baccatus, Zygophyllum coccineum, Otostegia fruticosa and Chiliadenus montanus. Five female ibex (Capra nubiana) were seen climbing rapidly over the ridge of Wadi Zeliga.

Day 3. This consisted of walking from Wadi Orma, and down Wadi Isla proper which, according to our guide, starts at a large grove of bamboo where Wadi Om Arad joins the main wadi. The dominant plants here are both species of Capparis, Raetam raetam, and Hyoscyamus boveanus. Also common are Calotropis procera, Pulicaria undulata and, increasingly, Pulicaria incisa. Other plants recorded were Cleome droserifolia, Acacia tortilis raddiana, Seriphidium herb-alba, Ochradenus baccatus, Ficus pseudosycomorus and Zilla spinosa. The abundance of Seriphidium and Zilla declined, and we could find no Reaumuria. In Wadi Om Arad we found Echinops spinossissimum close to the large deep pools of water at the mouth of that steep wadi.

The density of bamboo thickets is quite remarkable in places, especially at the end of the day's journey close to where we finally camped, at the mouth of Wadi Moagid (at $28^{\circ} 16^{\prime}$ $22.0^{\prime \prime} \mathrm{N}, 33^{\circ} 54^{\prime} 19.6^{\prime \prime} \mathrm{E}$, altitude $630 \mathrm{~m}, \mathrm{PDOP}=2.9, \mathrm{n}=5$ satellites). At this point the bamboo grows in a site with a large amount of running surface water on the wadi bed; in the densest region the path leads under overarching bamboo thickets and through dense stands of Mentha 
lavandulacea. There were many camel ticks in this site, sitting on the inflorescences with front legs held open, waiting for passing animals on which to mount.

In Wadi Isla at this point, the main plants are bamboo (Phragmites sp.), Pulicaria undulata, Zygophyllum album, Mentha lavandulacea, and Juncus rigidus. Other obvious plants are Fagonia tristis, Capparis spinosa, Acacia tortilis raddiana, Raetam raetam, Cleome droserifolia, Phoenix dactylifera, Echinops spinossissimum and Chrozophora oblongifolia.

Day 4. was spent censusing insect visitors to Mentha in two places in Wadi Isla close to the junction with Wadi Moagid.

Day 5. was spent censusing visitors to Mentha in Wadi Isla and Wadi Moagid. The latter wadi has a lot of running water near its junction with Wadi Isla, and the dominant plants are Mentha lavandulacea, Typha domingensis, Phragmites sp, Pulicaria undulata, Pulicaria incisa and Hyoscyamus boveanus. Other plants present are Solanum nigrum, Capparis spinosa, C. sinaica, Fagonia tristis, Zilla spinosa, Raetam raetam, Reseda urnigera, and Phoenix dactylifera.

In the late afternoon, we moved $2 \mathrm{~km}$ further down Wadi Isla, through a spectacular narrow gorge only 4-5 m wide. This gorge is rocky, very steep-sided, and full of running water and some accompanying plants (dominated by Mentha). According to our Bedouin guide, the vegetation is regularly swept away in spectacular flash floods which, in this narrow gorge, reach 6 m depth. Our camp site was at $28^{\circ} 15^{\prime} 2.5^{\prime \prime} \mathrm{N}, 33^{\circ} 55^{\prime} 11.3^{\prime \prime} \mathrm{E}$; the narrowness of the valley meant that only three satellites were received by the GPS $(\mathrm{PDOP}=2.9)$ and therefore it could not estimate our altitude.

Day 6. was spent censusing visitors to Mentha, and again in the late afternoon we moved to our final camp site in Wadi Isla close to the mouth at El Qa'a plain.

Day 7. We walked to the Bedouin settlement at the mouth of Wadi Isla, resting there until 1800. Overnight we walked north-west across the plain of El Qa'a skirting the edge of the mountains, past successive mouths of wadis Imleha, Shediq, Wagran, Mi'r, and finally to reach Wadi Hebran in the early morning (about $28^{\circ} 23^{\prime} \mathrm{N}, 33^{\circ} 42^{\prime} \mathrm{E}$ ).

Day 8. We walked $4 \mathrm{~km}$ up Wadi Hebran to a camp site at $28^{\circ} 31^{\prime} 21.3^{\prime \prime} \mathrm{N}, 33^{\circ} 41^{\prime} 35.1^{\prime \prime} \mathrm{E}$, at an altitude of $480 \mathrm{~m}$ (PDOP $=5.2, \mathrm{n}=5$ satellites). There is a great deal of water in this short $( \pm 1 \mathrm{~km})$ section near the mouth, and dense vegetation including an avenue of continuous Mentha lavandulacea, many date palms (Phoenix dactylifera) and a great deal of Juncus rigidus. The Mentha at this point is much denser than in Wadi Isla. Pulicaria undulata is also dominant. We also identified Zilla spinosa, Acacia tortilis raddiana, Cleome droserifolia, Citrullus colocynthis, two species of Zygophyllum (album and simplex), Hyoscyamus boveanus and Zosima absinthifolia.

Day 9. consisted of the walk up Wadi Hebran to the head of the wadi, into Wadi El-Ghotiah and over the mountain trail into Wadi Solaf. Apart from one well at about the mid-point, the whole of the rest of Wadi Hebran was without water; the dominant plant was undoubtedly Acacia tortilis raddiana, with date palms Phoenix dactylifera in the area of the well. Raetam raetam was absent, but present in Wadi El-Ghotiah. Wadi Solaf was the end of the expedition, and from there we returned to St Catherine.

\section{Table 1: The recorded plants}

\author{
Scientific Name \\ Asclepiadaceae \\ Calotropis procera (Ait.) Ait \\ Boraginaceae \\ Gomphocarpus sinaicus Boiss \\ Alkanna orientalis (L.) Boiss \\ Capparaceae
}

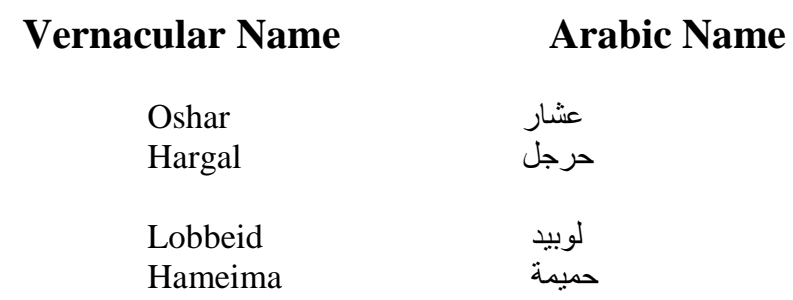


Capparis spinosa $\mathrm{L}$.

Capparis sinaica Duhamel

Cleomaceae

Cleome africana Botsch.

Cleome droserifolia (Forssk.) Del.

Compositae

Achillea fragrantissimum (Frossk.)

Seriphidium herba-alba (Asso) Sojak

Artemisia judaica L.

Centaurea scoparia Sieber

Echinops spinossissimus Turra.

Launaea spinosa (Forssk.) Sch.Bip.

Pulicaria incisa candolleana G. Eldin

Pulicaria undulata (L.) May.

Chiliadenus montana (Vahl.) Brullo.

Cruciferae

Moricandia nitens (Viv.)

Zilla spinosa (Turra) Prantl

Cucurbitaceae

Citrullus colocynthis (L.) Schrad.

Ephedraceae

Cucumis prophetarum Jusl. ap L.

Euphorbiaceae

$$
\text { Ephedra aphylla Forssk. }
$$

Chrozophora tinctoria (L.) Raf.

Chrozophora oblongifolia (Delile) Spreng.

Euphorbia obovata Decne.

Juncaeae

Labiatae

$$
\text { Juncus rigidus Desf. }
$$

Lavandula pubescens Decne

Mentha lavandulacea Willd.

Micromeria sinaica Benth.

Otostegia fruticosa (Forssk.)Brig.

Stachys aegyptiaca Pers.

Teucrium polium L. s.l. T. leucocladum

Leguminosae

Astragalus sp.

Acacia tortilis raddiana (Savi.) Brenan

Raetam raetam (Forssk.) Heywood

Moraceae

Ficus pseudosycomorus Decne.

Palmae

Resedaceae

$$
\text { Phoenix dactylifera } \mathrm{L} \text {. }
$$

Caylusea hexagyna (Forssk.)

Ochradenus baccatus Del.

Reseda urnigera Webb

Solanaceae

Hyoscyamus boveanus (Dun.)

Solanum nigrum $\mathrm{L}$.

Tamaricaceae

Reaumuria hirtella Jaub. et Sp.

Tamarix aphylla (L.) Karst

Typhaceae

Typha domingensis (Pers.) Poir.

Umbelliferae

Deverra tortuosa (Desf.) DC

Zozima absinthifolia (Vent.) DC

Zygophyllaceae

Fagonia tristis Sickenb.
Lasoof

Lasaf

Maganena

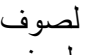

لصف لصوف

مجانينا

Qaysoom

Sheeh

Sheeh

Borkana

Khosheer

Kebathah

قيصوم

شيح

شيخح

خشير

كباثة

Rablah

Neheda

ربلة

نهيدة

Khasw el gamal

Thela

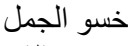

ثلة

Hazal

Hanzalaan

حنظل

حنظلان

Algan

علجان

Sammo

Om el Bena

سمو

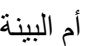

Dees

ديس

Zeita

زييتة

Habaq

Khassah

Sharma

Qortom

Ga'da

حبج

شرمة

قرطم

جعدة

Sayaal

سيال

Rataam

رنت

Hamaat

حماط

Nakal

نخل

Zenaba

زنابة

Qardi

قردى زنابة

Khesaama

خز امة

Sakraan

سكران

Enabah

عنابة

Melliha

Athl

مليحة

آثل

Bardi

بردى

Amiya

Waraqa

ور اقة 
Peganum harmala L.

Zygophyllum album $\mathrm{L}$.

Zygophyllum coccineum $\mathrm{L}$.

Zygophyllum simplex L.
Harmal

Rotreyt

Qalama

Qarmal

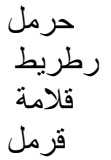

\section{Table 2: The Insects recorded}

\section{Coleoptera}

Alleculidae

Anthicidae

Buprestidae

Carabidae

Cerambycidae

Chrysomelidae

Coccinellidae

Curculionidae

Dermestidae

Dryopidae

Dytiscidae

Elateridae

Gyrinidae

Hydrophilidae

Melyridae

Trogossitidae

Scarabaeidae

Staphylinidae

Tenebrionidae
Mycetocharina megalops Fairm.

Formicomus sp. (3 species on Mentha)

Anthaxia sp.

Psiloptera mimosae (Klug) viridis

Ptychomus politus (Klug) on Acacia

Abacetus quadripustulatus Peyer

Bembidion sp.

Chlaenius canariensis seminitidus Chd

Pheropsophus africanus Dej.

Scarites sinaiticus Schatz

Stenolophus abdominalis Gene

Crossotus sp. (on Acacia in W. Isla).

Cryptocephalus sp.

Coccinella undecimpunctata (on Mentha)

Epilachna chysomelina orientalis Zimm (on Cucumis prophetarum Jusl.).

Apion alfierii Pic.

Coniatus aegyptiacus Cap.

Cylindropterus luxeri Chvr.

Lixus spp. (2 species).

Attagenus sp. (on the ground).

Anthrenus coloratus (on Umbelliferae).

Dryops luridus (Erichsen) (aquatic in all wadis)

Aglymbus gestroi Sharp

Cybister tripunctatus (Olivier) africanus (Laporte de Castelnau)

Deronectes arabicus Sharp

Deronectes schweinfurthii Zimm.

Eretes sticticus Steph

Hydaticus decorus Klug

Hydaticus leanderi Rossi

Hydroglyphus major (Sharp)

Hydrovatus cuspidatus (Kunze)

Hyphydrus sp.

Nebrioporus walkeri (van den Branden)

Nebrioporus lanceolatus (Walker)

Nebrioporus insignis (Klug)

Rhantus pulverosus Steph

Caradiophorus dilutus Er.

Dineutes grandis Klug

Enochrus bicolor (Fabr.)

Loccobius sinuatus Motsch.

Spercheus cerisyi (Guérin-Ménéville)

Melyris sinaita Pic

Tenebroides mauritanicus L.

Onthophagus sellatus Klug

Phyllognathus excavatus Forst.

Philonthus sp.

Adesmia sinaitica Croten

Mesomorphus sp.

Mesostena angustata $\mathrm{F}$.

Mesostenopa cavatica Andres

Ocnera hispida Forskal

Ocnera philistina Reiche 


\section{Dictyoptera}

Blattidae

Mantidae

Diptera

Asilidae

Bombylidae

Calliphoridae

Conopidae

Otitidae

Stratiomyidae

Tabanidae

Trypetidae

\section{Heteroptera}

Anthocoridae

Belostomatidae

Corixidae

Lygaeidae

Miridae

Nepidae

Pentatomidae

Rhopalidae

Tingidae

\section{Homoptera}

Membracidae

\section{Hymenoptera}

Anthophoridae

Eumenidae

Formicidae

Masaridae

Megachilidae

Pompilidae

Sapygidae

Scoliidae

Sphecidae
Opatroides punctatus Brulle

Tentyria sinaitica Sol.

Polyphaga aegyptiaca $\mathrm{L}$.

Eremiaphila sp.

Promachus sp.

Exoprosopa aegina Wied.

Pterobates chalybaea (von Röder) [new record for Egypt, reported in the 1999 World Catalog by Greathead]

Spogostylum isis Meigen

Spogostylum ocyale Wiedemann

Chrysomyia albiceps Wied.

Conops flavicaudus Bigot

Physocephala pusilla Meigen

Physiophora demandata Fabr.

Odontomyia sp.

Tabanus spp. (2 species).

Trypanea nostrata Hendel

Orius laevigatus (Fieber)

Lethocerus niloticus (Stal)

Sphaerodema urinator (Dufour)

Sigara spp. (2 species).

Nysius cynoides (Spin.)

Spilostethus longulus Dall.

Creontiades sp.

Laccotrephus fabricii Stál

Aspongopus viduatus unicolor H.S.

Bagrada amoenula Horv.

Sciocoris conspurcatus Klug

Ventocoris obsesus (Stál)

Liorhyssus hyalinus (Fabr.)

Copium sp (only one species in Egypt, teucrii Host)

Sangroneusa sp.

Anthophora albigena afra Priesner

Xylocopa pubescens Spinola

Xylocopa sulcatipes Maa

Delta asina mixtum (Giordani Soika) [recorded for Egypt by Giordani Soika, but this is the first Egyptian specimen]

Delta dimidiatipenne (Saussure)

Delta hottentottum elegans (Saussure)

Euodynerus stigma (Saussure)

Rhynchium cyanopterum (Saussure)

Camponotus cognatocompressus Forel

Monomorium sp.

Quartinia sp.

Anthidium sp1

Anthidium sp2

Chalicodoma maxillosa (Guerin)

Megachile submucida Alfken

Ctenagenia vespiformis Klug

Sapyga sp.

Dielis collaris (Fabr.)

Scolia erythrocephala Fabr.

Bembix dahlbomi Handlirsch

Bembix oculata Panzer 
Lepidoptera

Vespidae

Nymphalidae

Pieridae

Orthoptera

Satyridae

Acrididae

Gryllotalpidae

Tettigoniidae
Bembix olivacea Fabr.

Bembix rufiventris Priesner

Cerceris fisheri Spinola

Cerceris sabulosa (Panzer)

Chlorion hirtum (Kohl)

Chalybion flebile (Lepeletier)

Liris sp.

Philanthus coarctatus Spinola

Philanthus sp

Philanthus sp

Podalonia tydei (Le Guillou)

Prionyx crudalis (F. Smith)

Prionyx judaeus (de Beaumont)

Prionyx niveatus (Dufour)

Prionyx subfuscatus (Dahlbom)

Prionyx viduatus (Christ)

Sphex fumicatus Christ

Stizus sp1 (coloured like Bembix)

Stizus marthae Handlirsch

Stizus fuscatus Morice

Stizus savignyi Spinola

Tachysphex sp1

Tachysphex sp2

Vespa orientalis $L$.

Vanessa cardui L.

Euchloe glauconome $\mathrm{Ob}$.

Colotis fausta Oliv.

Pseudotergumia pisidice Klug

Acridella sp.

Poecilocerus bufonius Klug

Sphigonotus carinatus Sauss.

Gryllotalpa africana Beauv.

Phaneroptera cleomis Ayal et al. (on Cleome droserifolia)

Table 3: The Arachnida recorded

\section{Order: Scorpionida}

Buthidae

Leiurus quinquestriatus

Compsobuthus werneri

\section{Order: Araneida}

Orthochirus innesi

Araneidae

Clubionidae

Cheiracanthium

Hetropodidae

Gnaphosidae

Pterotricha

Loxoscelidae

Lycosidae

Loxosceles

Oxyopidae

Oxyopes

Peucetia
El-Sebaiya, 30.7.1994; 1: Wadi Isla, 4-5.8.94

Wadi Abu-Orma, 2.8 .94 (2); Wadi Isla, 4-5.8.94; Wadi Isla, 6.8 .94 (2); Wadi Hebran, 8.8.94

Wadi Mi'ar, 7.8 .94 (1); Wadi Hebran, 8.8.94 (5)

Wadi Hebran, 8.8 .94 (1sM, 2j)

Wadi Hebran, 8.8.94 (1M, 1j)

Wadi Hebran, 8.8 .94 (1j); Wadi Rahaba, 31.7 .94 (1j)

El-Sebaiya, 30.7.1994 (1F, 1sF); Wadi El Rahba, 31.7 .94 (1sM); Wadi Isla, 45.8 .94 (2F,1j); Sahl El-Qa'a, 6.8 .94 (1F,1j); Wadi Hebran, 8.8.94 (4F,1sF, $1 \mathrm{sM}, 2 \mathrm{j})$

Wadi Isla, 4-5.8.94 ((1sF); Wadi Hebran, $8.8 .94(1 \mathrm{sF})$

Wadi El Tarfa, 1.8.94 ((1sF); Wadi Isla, 4-5.8.94 (1M,1F); Wadi Hebran, 8.8.94 (1M,2F,1sF)

Wadi El Tarfa, 1.8.94 (1M); Wadi Hebran, 8.8.94 (1M)

Wadi El Tarfa, 1.8.94 (1F,2sF,6j); Wadi Hebran, 8.8.94 (3F,3sF,9j) 
Philodromidae

Pholcidae

Salticidae

Theridiidae

Thomisidae

Dzyptila sp.

Synema diana

Thomisus bidentatus

Thomisus onustus

Order: Pseudoscorpionida

Olpiidae

Olpium sp.

Withiidae

Withius sp.

Chernetidae

\section{Order: Solpugida}

Daesiidae
Wadi Isla, 6.8.94 (4F); Wadi Hebran, 8.8.94 (5F,1j)

Wadi Hebran, 8.8.94 (1F)

Wadi El Tarfa, 1.8.94 (1M); Sahl El Qa'a, 6.8.94 (2M); Wadi Isla, 4-5.8.94 (1M,1j); Wadi Hebran, 8.8.94 (4M,3j)

Wadi El Tarfa, 1.8.94 (1F); Wadi Isla, 6.8 .94 (1F); Wadi Hebran, 8.8.94 (2F)

Sahel El No'amani, 31.7.94 (1sF); El Tarfa, 1.8.94 (1sF); Wadi Isla, 2.8.94 $(2 \mathrm{sF})$

El Tarfa, 1.8.94 (1F); Wadi Isla, 2.8.94 (2M,1F)

El Tarfa, 1.8.94 (1M,2F); Wadi Isla, $2.8 .94(11 \mathrm{M}, 11 \mathrm{~F}, 2 \mathrm{sF})$; Wadi Isla, 4$5.8 .94(2 \mathrm{~F}, 1 \mathrm{sF})$

El Tarfa, 1.8.94 (1M); Wadi Isla, 2.8.94 (1M,4sM,1j,1F,1sF,4j); Sahl El Qa'a, $6.8 .94(1 \mathrm{sF})$

Sahel El No'amani, 31.7.94 (1M,1F); Wadi Isla, 2.8 .94 (1M); Wadi Isla, 45.8.94 (1F); Wadi Hebran, 8.8.94 (2M,2F)

Wadi Abu O'rma, 2.8.94 (2M,1F); Wadi Hebran, 8.8.94 (2M,1F)

Wadi Isla, $2.8 .94(2 \mathrm{j})$

Wadi Isla, 2,4-5.8.94 (2); Wadi Ma’ar, 7.8.94; Wadi Hebran, 3.8.94 (3)

In conclusion, we recorded 20 plant families with 51 species, including many Compositae; and eight insect orders, 54 families and 138 species, dominated by beetles, wasps and bees. There were four orders of Arachnida: Araneida with 12 families, 16 species and 91 specimens; Pseudoscorpionida with 3 families, 3 species and 8 specimens; Scorpionida with 1 family, 3 species and 11 specimens; and Solpugida with 1 family, 1 species and 3 specimens.

\section{Acknowledgements}

We thank the Environmental Research Center for accommodation and laboratory facilities; our sincere thanks and appreciation goes to our Bedouin Guide, Hussein No'man from Rahaba, for his guidance and help with plant identification. We also extend our thanks to the Bedouin communities at the mouth of Wadi Isla, for their hospitality and providing us with a delicious hot meal. We are grateful to Mr. Hesham El-Hennawy for identifying the spiders and scorpions.

\section{References}

Boulos L (1998-2004) Flora of Egypt. 4 vols. El Hadara Publishing, Cairo.

Boulos L \& Gibali M (1993) List of the rare, vulnerable, endangered and endemic species of vascular plants in the Sinai peninsula. Unpublished ms.

Danin A, Shmida A \& Liston A (1985) Contribution to the Flora of Sinai. III. Checklist of the species collected and recorded by the Jerusalem team 1967-1982. Willdenowia 15:255-322.

Dumont HJ (1991) Odonata of the Levant. Fauna Palaestina-Insecta V. Israel Academy of Sciences, Jerusalem.

Freidberg A \& Kugler J (1989) Diptera: Tephritidae. Fauna Palaestina-Insecta IV. Israel Academy of Sciences, Jerusalem.

Gamal El Din S (1992) St Katherine National Park: Floristic studies. Report on Environmental studies towards establishing St Katherine National Park, submitted to the Environmental Protection Agency, National Park Department, by Suez Canal University.

Gilbert F \& Zalat S (2008) The butterflies of Egypt: atlas, Red Data listing \& conservation. Illustrated by Ahmed Gheith. BioMAP, EEAA, Cairo

Larsen T (1990) The butterflies of Egypt. American University in Cairo Press, Cairo \& Apollo Books, Denmark.

Shoqair N (1916). The History of Sinai. [In Arabic] published by the Monastery of St Catherine, Sinai.

Zahran MA \& Willis AJ (1992) The Vegetation of Egypt. Chapman \& Hall, London.

Tackholm V (1974) A Students Flora of Egypt. 2nd edition. Cairo University Press, Cairo.

Theodor O (1980) Diptera: Asilidae. Fauna Palestina. Insecta II. Israel Academy of Sciences, Jerusalem. 
Zalat SM (1983) Survey and ecological studies of bees and wasps (Hymenoptera) in southern Sinai. MSc thesis, Suez Canal University, Ismailia.

\section{الملخص العربيى}

الحصر البيولوجى لثبه جزيرة سيناء: الفلورا والفونا فى وادى إسلا وحبران ـ محمية سانت كاترين ـ مصر

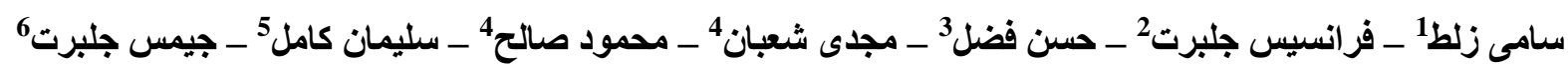

$$
\begin{aligned}
& \text { 1 - قسم علم الحيوان ـ كلية العلوم - جامعة قناة السويس ـ الإسماعيلية ـ مصر }
\end{aligned}
$$

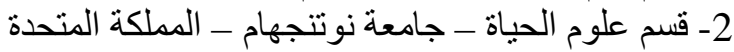

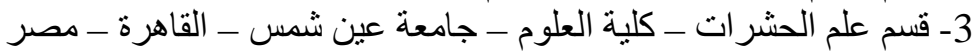

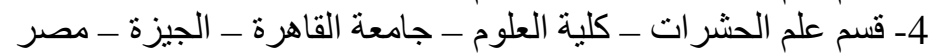

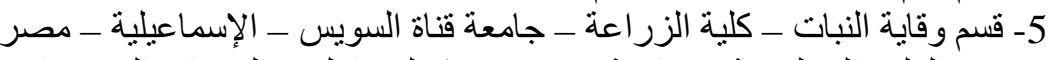

$$
\begin{aligned}
& \text { 6- قسم العلوم البيولوجية - جامعة ميريلاند ـ كولج بارك ـ الو لايات المتحدة الإمريكية }
\end{aligned}
$$

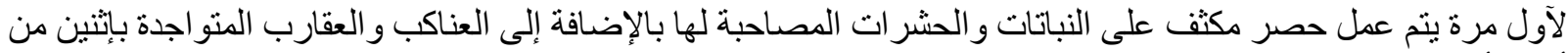

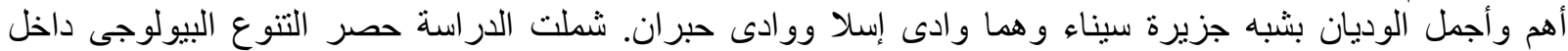

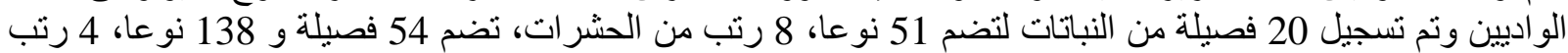

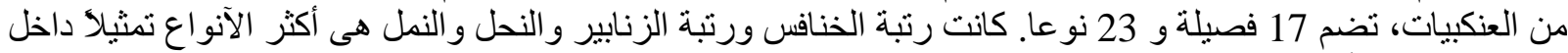

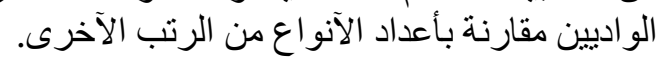

